\title{
Describing student's mathematical power: Do cognitive styles make any difference?
}

\author{
Harina Fitriyani*, Fariz Setyawan, Aan Hendroanto, Vita Istihapsari \\ Universitas Ahmad Dahlan, Jl. Ahmad Yani, Tamanan, Bantul, DIY 55711, Indonesia \\ *Corresponding E-mail: harina.fitriyani@pmat.uad.ac.id
}

\section{ARTICLE INFO}

\section{Article History}

Received 16 March 2021

Revised 21 March 2021

Accepted 21 March 2021

\section{Keywords}

Cognitive style

Impulsive

Mathematical power

Reflective

How to cite this article: Fitriyani, H., Setyawan, F., Hendroanto, A., \& Istihapsari, V. (2021). Describing student's mathematical power: Do cognitive styles make any difference?. Bulletin of Applied Mathematics and Mathematics Education, 1(1), 39-46.

\section{ABSTRACT}

Mathematical power refers to the skills of students in reasoning, connection, communication, representation, and problem-solving. Various researchers have massively discussed on how to foster mathematical power. However, it is just a few of them comprehensively explain from the cognitive styles' perspective. This research aims to measure the junior high school students' mathematical power based on their cognitive style. This research used a descriptive qualitative approach. There were 35 students took part in the mapping of cognitive styles using the Matching Familiar Figure Test and were then selected representative from the reflective and the impulsive cognitive style to have a further assessment of the mathematical power using the mathematical power test. The data analysis used the model of Milles and Huberman. The results showed that there was a difference mathematical power between the subject having an impulsive cognitive style and the one having reflective cognitive style. The percentage of mathematical power of reflective subject was $69 \%$ while the impulsive subject was $56.89 \%$. From all aspects of mathematical power, the reflective subject tends better ability; for instance, the reflective subject has better ability than the impulsive subject on mathematical connection, mathematical reasoning, mathematical representation, and problem-solving.

This is an open access article under the CC-BY-SA license.

\section{Introduction}

In recent years, mathematics education has demanded a significant change to adapt to the challenge of students' 21st-century skills, especially the ability of problem solving and communication. According to NCTM (2000), all the skills previously mentioned, such as mathematical communication, mathematical connection, mathematical reasoning, mathematical representation, and problem-solving, are known as mathematical power. Therefore, mathematical power holds the key to changed mathematics education to aid students' learning. Having the study's importance, the researchers need to investigate students' mathematical power in the future.

There are five aspects of mathematical power. The first aspect is mathematical communication. This aspect includes creating a mathematical situation based on ideas and information from a problem; expressing ideas, situations, or mathematical relations in the form of 
images, graphs, or algebraic forms; expressing ideas situations or mathematical connections in the language/symbol of mathematics; interpreting and evaluating ideas, conditions, or relationships with responses in the form of arguments (Bruner \& Kenney, 1965; Jacobs et al., 2006; Sumarmo, 2010). The second aspect, mathematical connection, is indicated by how the students recognized and used relationships between mathematics ideas, understanding how concepts in mathematics interconnected to each other to produce a unified whole, identifying and applying mathematics into the environment outside mathematics (NCTM, 2000).

The third aspect is mathematical reasoning ability. The indicators are (1) giving explanations by using models, facts, properties, and relationships, (2) drawing logical conclusions based on the models, facts, traits, and relationships, (3) compiling and testing conjectures; (4) providing reasons for solutions to problems encountered, and (5) analyzing mathematical situations using patterns and relationships (Jacobs et al., 2006; NCTM, 2000). The next aspect, mathematical representation, is seen as the student's understanding of mathematics concepts. To determine the subject's understanding, the researchers can use a mathematical representation of the topics or ideas (Setyawan, 2017; Panasuk, 2011). It is because mathematical representation also becomes the base of a higher level of students' understanding (Hendroanto et al., 2015). The last aspect, problemsolving ability, is closely related to Polya's (1976) problem-solving steps that include understanding the given problem, devising a plan to solve the problem, carrying out the plan, and then looking back. However, the mastery of each aspect is varied among the students, especially junior high school students in Indonesia.

Many factors are influencing the development of students' mathematical power. One of those factors is students' cognitive style. Each student certainly has different characteristics and cognitive styles. There are four types of students' conceptual cognitive styles. They are reflective (slow but accurate), impulsive (fast but inaccurate), slow inaccurate, and fast accurate (Witkin, 1973). Warli (2013) found that there are two important considerations in measuring reflective-impulsive cognitive style. The first consideration is the ability of the subject to describe the accuracy of the problem-solving claim or the time to decide problem-solving, and the second is the existence of uncertain answers. The time aspect is divided into two, namely fast and slows, while the uncertainty aspect so divided into two that is accurate and inaccurate. The students can be categorized into four based on the combination of time and uncertainty aspects: fast-accurate, slow and accurate (reflective), fast and inaccurate (impulsive), slow-inaccurate. How each category influences the development of students' mathematical power is still unknown. Usodo (2011) and Ulya (2015) only studied how cognitive styles contribute to students' problem-solving skills, while Ramlah (2015) investigated students' interactivity in the class based on their cognitive style. Therefore, a more thorough study of how students' cognitive style influences their mathematical power is needed.

The research aims to find out the relationship between students' cognitive style and their mathematical power. It describes the result found during the study but focuses on reflective and impulsive cognitive style. The reason why the researchers choose reflective-impulsive types is that these styles are the most dominant compared to the other styles (Warli, 2013; Rozencwajg \& Corroyer, 2005; Fitriyani \& Khasanah, 2017; Prihastanto \& Fitriyani, 2017; Apriyanti \& Fitriyani, 2017; Amimah \& Fitriyani, 2016; Fitriyani \& Khasanah, 2017). The student's characteristics, which reflect the cognitive style, are slow in solving the problem, but the solution tends to be precise. Whereas students who have impulsive cognitive styles are fast in solving the problem, but the answers tend to be inaccurate. 


\section{Method}

This study was descriptive qualitative research. The subjects were the students who had dominant reflective and impulsive cognitive style in $8^{\text {th }}$ grade of SMP Muhamamdiyah 1 Gamping, Sleman. The researchers were selecting the subject of the research using purposive sampling. The researchers collected the data in the even semester of 2016. The study was using tests, interviews, and documentation methods. The Matching Familiar Figure Test (MFFT) and a mathematical power test is used as the instrument to collect the data. The MFFT was adopted by Warli (2010). The MFFT was used to classify students' cognitive styles based on students' conceptual knowledge. Besides, the mathematical power test was used to determine students' mathematical communication, mathematical connection, mathematical reasoning, mathematical representation, and problemsolving. The validation of the mathematical power test was using construct validation. Thirty-five students took part in the MFFT test. So, the researchers selected two students from the reflective and the impulsive cognitive style in each to have a further assessment of the mathematical power. The researchers used the time triangulation technique to obtain data validity. Furthermore, the data analysis was using Milles and Huberman's model (2014), which included reduction of the data, presentation of the data, and conclusion.

\section{Results and Discussion}

It obtained information that most of the students' cognitive styles are reflective $(31,43 \%)$ and impulsive $(28,57 \%)$. There is also a tendency of multiple cognitive styles, the inaccurate and impulsive slow-reflective tendencies of 2.86\%. The findings of this MFFT result are the presence of one student who cannot be categorized by his cognitive style tendency based on conceptual tempo because his MFFT results are precisely on the intersection of the $t$-axis and f-axis. In other words, reflective and impulsive cognitive styles are the dominant cognitive stylistic tendencies among different categories. It supports the findings (Warli, 2013; Rozencwajg \& Corroyer, 2005; Fitriyani \& Khasanah, 2016; Prihastanto \& Fitriyani, 2017; and Fitriyani \& Khasanah, 2017). Figure 1 represents the summary of the percentage of students' cognitive-style tendencies.

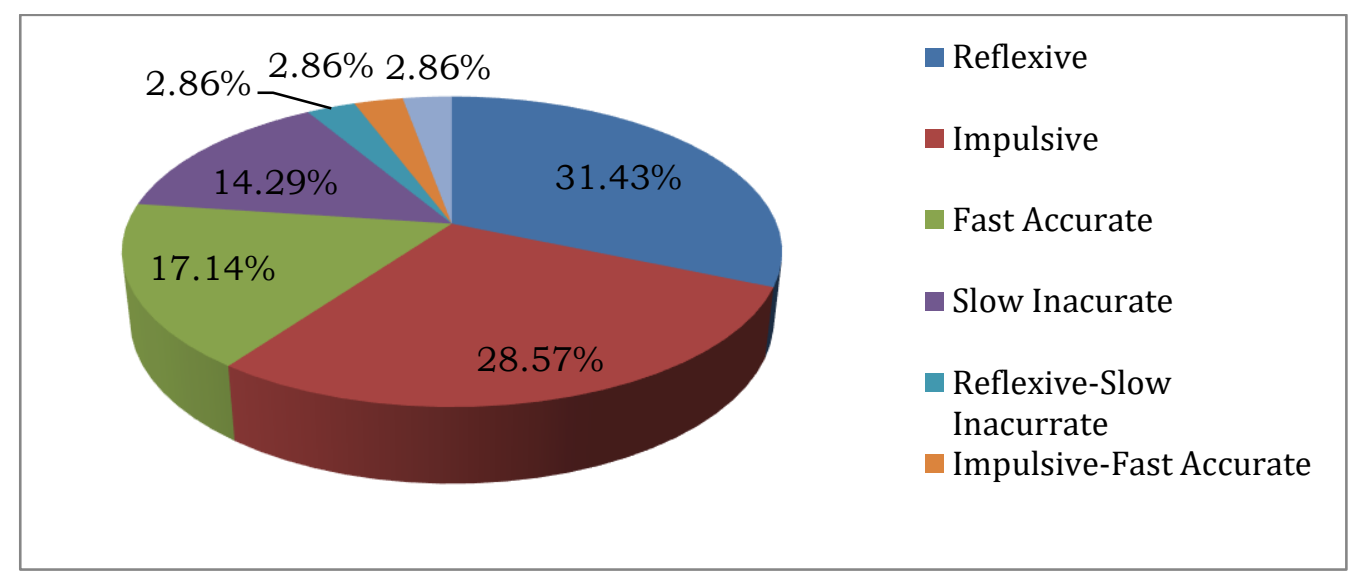

Figure 1. Mapping of Students' Cognitive Style.

Based on the result of the student's mathematical ability test, the founding is a clear result of the mathematical power of both reflective and impulsive subjects. Figure 2 dish up the summarize of the difference (in percentage) of each ability that characterizes the ability of mathematical power. 


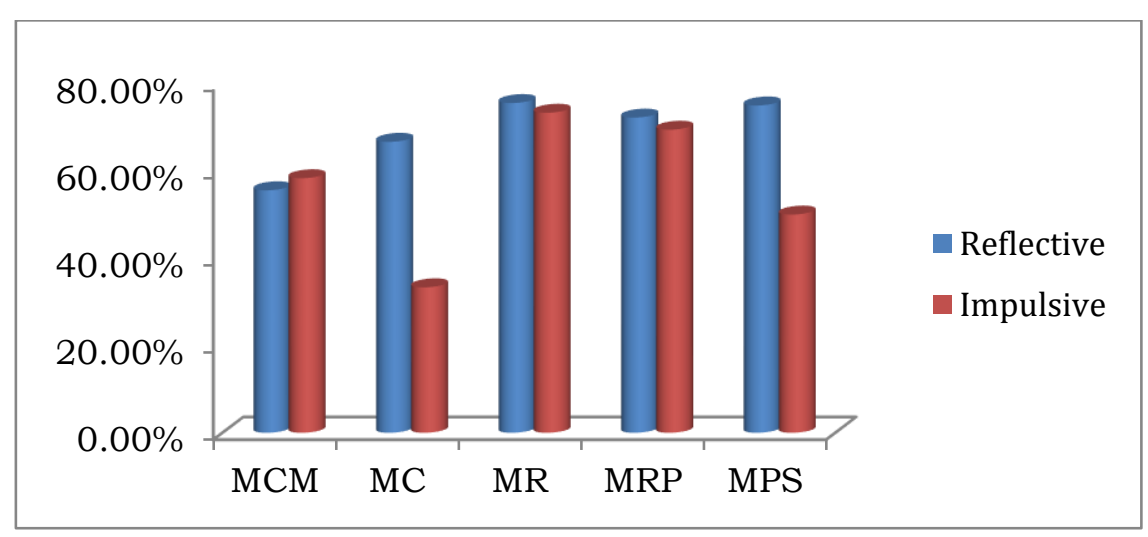

Figure 2. Percentage of mathematical power based on cognitive style

Figure 2 shows that the mathematical power of the impulsive subject is better than the reflective subject (see Figure 2). Both subjects can explain information and ideas that are understood the problem to help solve the problem. It was found that the reflective subject was writing it on the answer sheet correctly. Besides, the impulsive subject was not writing it on the answer sheet. Concerning the idea, the mathematical situation in the form of images, graphs, or algebraic forms, both impulsive and reflective subjects can visualize the idea captured from the given problems in a simple image form without adding any description that supports the description of the image it makes. Also, the impulsive subject can express the mathematical situation in the algebraic form to solve the problem appropriately. While the reflective subject expresses mathematical ideas in algebraic form but on the use of square area formulas, there is still a fallacy where the subject assumes that the square area is $4 \mathrm{~s}$ where $\mathrm{s}$ is the square side length. Regarding the use of mathematical symbols or mathematical notations, impulsive subjects have used mathematical symbols and correctly translated the problem into a mathematical model. While the reflective subject used mathematical symbols and translates the existing symbol, but it was not perfect. Like the subject's inability to translate the symbol "//" on the flat-side edges, which means that the sides are the same length. In the case of interpretation of the mathematical situation in the form of argument, the two subjects do not yet have a good understanding of the concept of wakeup given so that they are unable to interpret the mathematical situation in the form of argument correctly and problem-solving is still not correct.

In the second aspect of mathematical power, the subject's mathematical connections; reflective subjects have better mathematical connection capabilities than impulsive subjects. Reflective subjects recognized and used relationships among ideas in mathematics, such as the relationship between the concept of square area and square circumference, while the impulsive subject had not been able to connect ideas in mathematics. Reflective subjects can understand how the idea of the area of a square and the circumference of rectangles are interconnected and construct one another to produce the exact solution of the problem while the impulsive subject had not been able to do this. In the application of mathematics into environments outside mathematics, reflective subjects can use mathematical concepts for problem-solving, but the implicative subject had not succeeded in doing this.

In the mathematical reasoning abilities, both subjects were able to explain by using the facts that exist on the problem and relationships with other things by the question. The impulsive subject is capable of concluding the realities that appear on the matter, and the connection is less precise in the way the reflective subject does so but is less than perfect. Reflective subjects can arrange 
conjectures well, while impulsive subjects have not done so correctly because the subjects did not complete the job as they should. Regarding the reason for the solution, both subjects have not been able to provide the exact cause. While regarding mathematical situation analysis, the reflective subject has not analyzed it by using appropriate algebraic patterns. So is the impulsive subject.

In the aspect of mathematical representation, both subjects were able to present information back to the problem in the form of a picture. The reflective subject can formulate a mathematical statement by the problem, but the subject's answer is less precise. In contrast, the Impulsive subject can create a mathematical expression appropriate to the triangle and quadrilateral images it produces. The reflective subject made the problem situation better than the impulsive subject, and the problem-solving step is more comprehensive than the impulsive. The impulsive subject tends not to write down the problem-solving steps. Thus, in general, the mathematical representation of the reflective subject is better than the impulsive subject.

The problem-solving ability of the reflective subject is better than the impulsive subject. Regarding understanding the problem, both subjects understand the given problem by stating what is known and asked the question correctly. At the planning stage, the reflective subject develops a plan of completion, although it is less precise in analyzing the problem while the impulsive subject prepares a plan of termination but less accurate in understanding the concept. The reflective subject to carry out the planning that has been prepared but not appropriate and impulsive subject to carry out planning but not by what has been planned. The reflective subject concludes and reexamines the steps and outcomes that have been used but are less precise, and the time at which subjects solve the problem tends to be slow while the impulsive subject re-examined the result of the work done but less accurate and faster worker time.

Based on the description of the above aspects of mathematical power, there is a difference in the overall ability of mathematical power between different subjects of cognitive (reflective and impulsive) styles. The mathematical knowledge of the reflective subject is better than the impulsive subject, where the percentage of mathematical understanding of the reflective subject is $69 \%$, and the impulsive subject is $56.89 \%$. The portion of indicator achievement aspects of mathematical power was below 70\%. It indicated the mathematical power of students is still lacking and need to be improved. These aspects of mathematical power is a skill required to be mastered by students as a form of achievement of general goals of learning mathematics (Sugilar, 2017; Ramlah, 2015).

\section{Conclusion}

The conclusion of this research is there were differences in the ability of mathematical power between reflective and impulsive subjects in which reflective subjects tend to better the knowledge of mathematical power is the competence of mathematical reflective subject $69 \%$ and the experience of mathematics subject of impulsive $56.89 \%$. Of the five aspects of mathematical power, the reflective subject tends mathematical connection ability, mathematical reasoning, mathematical representation, and better problem-solving of impulsive subjects. But the impulsive subject has better mathematical communication skills than the reflective subject.

\section{Acknowledgement}

We want to thank all students who participated in this study. The principal, Mrs. Umi Rochmiyati, S.Pd., has permitted us to do this research at school, and all mathematics teachers who provided various information we need. We also thank the research assistants, namely Alfian Riski Prihastanto, Dhaning Cahya Murti, Farah Hilmy Dwijayanti, Silvia Nur Eka Septianingsih, and Upyka Lestari Putri, for helping us collecting the data. 


\section{References}

Amimah, H. S. \& Fitriyani, H. (2017). Level berpikir siswa SMP bergaya kognitif refleksif dan impulsif menurut teori van Hiele pada materi segitiga. Proceeding in National Seminar on Education, Science, and Technology 2017, 133-138. Semarang: Universitas Muhammadiyah Semarang.

Apriyanti, S. \& Fitriyani, H. (2017). Teori van Hiele: Tingkat berpikir siswa SMP bergaya kognitif refleksif dan impulsif pada materi segiempat. Proceeding in National Seminar on Education, Science, and Technology 2017, 364-370. Semarang: Universitas Muhammadiyah Semarang.

Bruner, J. S., \& Kenney, H. J. (1965). Representation and mathematics learning. Monographs of the Society for Research in Child Development, 30(1), 50-59.

Fitriyani, H. \& Khasanah, U. (2016). Analisis kesalahan Newman (NEA) pada pemecahan masalah geometri mahasiswa ditinjau dari gaya kognitif. Proceeding in National Seminar on Mathematics Education 2016. Surabaya: Universitas Negeri Surabaya.

Fitriyani, H., \& Khasanah, U. (2017). Student's rigorous mathematical thinking based on cognitive style. Journal of Physics: Conference Series, 943(1), 012055.

Hendroanto, A., Budayasa, I. K., Abadi, A., Van Galen, F., \& Van Eerde, H. A. A. (2015). Supporting Students' Spatial Ability in Understanding Three-Dimensional Representation. Proceeding the Third South East Asia Design/Development Research (SEA-DR) International Conference 2015, 124-134. Palembang: Sriwijaya University.

Milles B. M., Huberman, A. M., \& Saldana, J. (2014). Qualitative data analysis: An expanded sourcebook. Los Angeles: SAGE Publications.

NCTM. (2000). Principles and Standards for School Mathematics. Reston: NCTM.

Prihastanto, A. R., \& Fitriyani, H. (2017). Profil kemampuan koneksi matematis siswa SMP yang bergaya kognitif reflektif-impulsif dalam menyelesaikan soal geometri. Jurnal Didaktika, 23(2), 89-98.

Panasuk, R. M. (2011). Taxonomy for assessing conceptual understanding in Algebra using multiple representations. College Student Journal, 45(2), 219-232.

Jacobs, J. K., Hiebert, J., Givvin, K. B., Hollingsworth, H., Garnier, H., \& Wearne, D. (2006). Does eighthgrade mathematics teaching in the United States align with the NCTM standards? Results from the TIMSS 1995 and 1999 video studies. Journal for Research in Mathematics Education, 37(1), 5-32.

Ramlah, R., Firmansyah, D., \& Zubair, H. (2015). Pengaruh Gaya belajar dan keaktifan siswa terhadap prestasi belajar matematika (Survey pada SMP Negeri di Kecamatan Klari Kabupaten Karawang). Majalah Ilmiah SOLUSI, 1(3).

Rozencwajg, P., \& Corroyer, D. (2005). Cognitive processes in the reflective-impulsive cognitive style. The Journal of Genetic Psychology, 166(4), 451-463.

Setyawan, F. (2017). Visualizer's representation in functions. Journal of Physics: Conference Series, 943(1), 012058.

Sugilar, H. (2017). Kompetensi matematis mahasiswa Program Studi Pendidikan Matematika. Jurnal JNPM, 1(1).

Sumarmo, U. (2010). Berfikir dan disposisi matematik: Apa, mengapa, dan bagaimana dikembangkan pada peserta didik. Bandung: FPMIPA UPI.

Ulya, H. (2015). Hubungan gaya kognitif dengan kemampuan pemecahan masalah matematika siswa. Jurnal Konseling GUSJIGANG, 1(2).

Usodo, B. (2011). Profil intuisi mahasiswa dalam memecahkan masalah matematika ditinjau dari gaya kognitif field dependent dan field independent. Paper presented at Nasional Seminar on 
Mathematics and Mathematics Education (pp. 95-102). Surakarta: Universitas Negeri Sebelas Maret.

Warli. (2013). Kreativitas siswa SMP yang bergaya kognitif reflektif atau impulsif dalam memecahkan masalah geometri. Jurnal Pendidikan dan Pembelajaran, 20(2), 190-201.

Warli. (2010). Matching Familiar Figure Test (MFFT). Unpublished paper. Surabaya: Universitas Negeri Surabaya.

Witkin, H. A. (1973). The Role of Cognitive Style in Academic Performance and in Teacher-Student Relations. New Jersey: Educational Testing Service. 
BAMME Vol. 1 No. 1, April 2021, pp. 39-46

This page is intentionally left blank. 